\title{
Diversity of Insect Pests and their Natural Enemies in Brinjal
}

\author{
R. Kumar, M.K. Mahla, G. Chhangani*, B. Singh and V. Kumar \\ Department of Entomology, Rajasthan College of Agriculture (MPUAT) Udaipur, India \\ *Corresponding author
}

\section{A B S T R A C T}

\section{Keywords \\ Brinjal, \\ Biodiversity, Insect pests, Natural enemies, Relative density \\ Article Info \\ Accepted: \\ 26 June 2018 \\ Available Online: \\ 10 July 2018}

\begin{abstract}
The investigation on, "diversity of insect pests and natural enemies in brinjal" was conducted at Horticulture Farm and Department of Entomology, Rajasthan College of Agriculture, Udaipur during kharif 2015. The seedling of brinjal variety "Kavach" was transplanted to record the different insect pests population and natural enemies diversity in the brinjal ecosystem. The diversity of insect pests infesting brinjal during 2015-16 comprised four species of sap sucking insects, the aphids, jassids, whiteflies and tinged bugs; the shoot and fruit borer and hadda beetle. On the basis of mean density, whiteflies had the maximum seasonal mean density 20.11 per 5 plants followed by aphids and jassids. The relative density was also the maximum (25.78) for whiteflies on account of their population abundance. Among the common natural enemies associated with their pests the maximum mean density (15.69) and relative density (42.91) was for the lady bird beetle; however, syrphid fly and spiders were also recorded. Among the major pests
\end{abstract}

\section{Introduction}

Brinjal (Solanum melongena L., solanaceae) also known as egg plant is native to India and an important vegetable crop grown throughout the world, especially in south Asia. In india, the total area under brinjal cultivation is 0.71 million hectares with an annual production of 13.57 million tons (Anonymous, 2014) and in Rajasthan the area under cultivation was 0.055 lac hectares with an annual production of 0.28 lac tons (anonymous, 2013). It is grown in many districts during summer and rainy season. Brinjal is a rich source of minerals (calcium, magnesium, phosphorus, sodium, potassium, chlorine and iron), vitamins and also has some medicinal importance (Choudhary, 1967).

The crop is infested by 26 species of insect pests and mites from germination to harvest (Vevai, 1970); among these, the shoot and fruit borer, Leucinodes orbonalis Guen.; jassid, Amrasca biguttula biguttula (Ishida); aphid, Aphis gossypii Glover; lace wing bug, Urentius echinus Distant; epilachna beetle, Epilachna vigintioctopunctata Fab., white fly, Bemisia tabaci (Genn.) and stem borer, Euzophera perticella Rag are major constraints in achieving the potential yield; 
besides, some of them remain active throughout the year with many overlapping generations (Atwal and Dhaliwal, 1976). Fruit infestation up to 70 per cent (Lal, 1964), 37.32 per cent (Tewari et al., 1984) and 32.42 per cent (Behera et al., 1999) have been reported on this crop. Rosaih (2001) reported as 70 to 90 per cent losses due to infestation by the shoot and fruit borer, jassid, and aphid.

\section{Materials and Methods}

The present investigation was conducted at Horticulture Farm of Rajasthan College of Agriculture, Udaipur, during 2015. The experimental field was prepared during the first week August, 2015 by ploughing with the help of disc plough followed by cross harrowing and planking. A well pulverized field was used for transplanting the seedlings (variety- Kavach). Experiment was laid out in randomized block design and replicated thrice. Transplanting of healthy seedlings was done during the second week of September, 2015 in plots measuring $3.6 \mathrm{~m} \mathrm{x} 3 \mathrm{~m}$ maintaining the row to row and plant to plant spacing as $60 \mathrm{~cm}$ x $45 \mathrm{~cm}$, respectively.

Appropriate sampling techniques were adopted for the estimation of population of different insect pests. The population of jassids, aphids and whiteflies were recorded on three leaves (upper, middle and lower) from the five tagged plants in each replication as per method suggested by Heathcote (1972) and Satpathy (1973). The population was estimated by gently holding the leaf between two halves of a Petri plate $(10 \mathrm{~cm}$ diameter) and the adults and nymphs within the Petri plate were counted. The nymphal population was counted with the help of magnifying lens and the data were expressed as numbers per three leaves.

The data obtained was subjected to suitable mathematical analyses to work out the mean density and relative density:
Mean density $=\frac{\sum X i}{\mathrm{~N}}$

Where, $\mathrm{Xi}=$ Number of insects or natural enemies in $i^{\text {th }}$ sample

$\mathrm{N} \quad=$ Total numbers of plants sampled.

Relative density $($ RD \% $)=$

$\frac{\text { Number of individual of one species }}{\text { Total number of individual of all species }} \times 100$

\section{Results and Discussion}

The crop season 2015-16 from September to January brinjal was infested by aphid, jassid, whitefly, brinjal shoot and fruit borer, Epilachna beetle and bug. Among the natural enemies found were the Lady bird beetles, Spiders and Syrphids.

Among the sucking insect pests aphids had a mean density of 17.59 with a relative density 22.55 percent, The jassid population had a mean density of 17.93 and relative density value of 22.98 per cent, The whitefly population had a mean density of 20.11 and relative density value of 25.78 per cent

The brinjal shoot and fruit borer population had a mean density of 10.53 and relative density value of 13.49 per cent, the Epilachna beetle population had a mean density of 4.80 and relative density value of 6.15 per cent during, Lacewing bug population had a mean density of 7.06 and relative density value of 9.05 per cent during.

The predatory insect population in which the lady bird beetle population had a mean density of 15.69 and relative density value of 42.91 per cent, the syrphid fly population had a mean density of 10.63 and relative density value of 29.01 per cent and the spider 
population had a mean density of 10.29 and relative density value of 28.08 per cent during 2015 -16 (Table 1).

Similar results were found in different experiments supporting our findings. Latif et al (2009) obtained the arthropod biodiversity in the brinjal field during February to August. Twenty species of harmful arthropods under 17 families were observed belonging to 6 different orders. The brinjal shoot and fruit borer (Leucinodes orbonalis), jassid (Amrasca biguttula biguttula), epilachna beetle
(Epilachna sp.) white fly (Bemisia tabaci) and aphid (Aphis gossypii) were found as the most common and major insect pests of brinjal. Ten plants dwelling predaceous arthropod families were found in the field among them $42.44 \%$ were occupied by three families under Coleopteran insect. Spider under lycosidae family possessed $30.23 \%$, which was ranked as the second most important arthropods. Ghosh and Chakraborty (2012) reported that the population of $C$. septempunctata was higher during September-October and declined in November.

Table.1 Diversity of insect pests and associated natural enemies in brinjal

\begin{tabular}{|l|l|l|l|l|l|}
\hline S. No. & \multicolumn{1}{|c|}{ Common Name } & \multicolumn{1}{|c|}{ Scientific Name } & \multicolumn{1}{|c|}{$\begin{array}{c}\text { Order and } \\
\text { family }\end{array}$} & $\begin{array}{c}\text { Mean } \\
\text { Density }\end{array}$ & $\begin{array}{l}\text { Relative } \\
\text { Density }\end{array}$ \\
\hline 1. & Shoot and fruit borer & Leucinodes orbonalis Guen & $\begin{array}{l}\text { Lepidoptera } \\
\text { Pyralidae }\end{array}$ & 10.53 & 13.49 \\
\hline 2. & Epilachna beetle & Epilachna vigintioctopunctata Fab & $\begin{array}{l}\text { Coleoptera } \\
\text { Coccinellidae }\end{array}$ & 4.80 & 6.15 \\
\hline 3. & Lace wing bug, & Urentius echinus Distant & $\begin{array}{l}\text { Hemiptera } \\
\text { Tingidae }\end{array}$ & 7.06 & 9.05 \\
\hline 4. & Aphid & Aphis gossypii Glover & $\begin{array}{l}\text { Hemiptera } \\
\text { Aphididae }\end{array}$ & 17.59 & 22.55 \\
\hline $\mathbf{5 .}$ & Jassid & Amrasca biguttula biguttula (Ishida) & $\begin{array}{l}\text { Hemiptera } \\
\text { Cicadellidae }\end{array}$ & 17.93 & 22.98 \\
\hline 6. & Whiteflies & Bemisia tabaci (Genn.) & $\begin{array}{l}\text { Hemiptera } \\
\text { Aleyrodidae }\end{array}$ & 20.11 & 25.78 \\
\hline 7. & Lady bird beetle & Coccinella septemunctata & $\begin{array}{l}\text { Coleoptera } \\
\text { Coccinellidae }\end{array}$ & 15.69 & 42.91 \\
\hline 8. & Syrphid fly & Syrphus spp & $\begin{array}{l}\text { Diptera } \\
\text { Syrphidae }\end{array}$ & 10.63 & 29.01 \\
\hline 9. & Spiders & Spider. & Araneae & 10.29 & 28.08 \\
\hline
\end{tabular}

\section{Acknowledgement}

The senior author is thankful to the Dean, Rajasthan College of Agriculture and Head, Department of Entomology, Udaipur for providing necessary facilities for the present investigation.

\section{References}

Anonymous, 2013. Indian Horticulture Data Base. 2013. National Horticulture
Board, Ministry of Agriculture, Government of India, Gurgaon, pp 286.

Anonymous, 2014. Indian Horticulture Data Base. 2014. National Horticulture Board, Ministry of Agriculture, Government of India, Gurgaon, pp 127-135.

Atwal, A. S. and Dhaliwal, G. S. 1976. Agricultural Pests of South Asia and their Management, Kalyani Publishers, Ludhiana. 
Behera, T. K., Singh, N., Kalda, T. S. and Gupta, S. S. (1999). Screening for shoot and fruit borer incidence in egg plant genotypes under Delhi condition. Indian J. Ento., 61: 372-375.

Choudhary, B. 1967. Brinjal vegetables. National book Trust, India, New Delhi, pp. 50-58.

Ghosh, S.K.R. and Chakraborty, K., 2012. Incidence and abundance of important predatory beetles with special reference to Coccinella septempunctata in sub-himalayan region of north -east India, Inter. J. Plant, Ani. and Environ. Sci., 2: 157162.

Heathcote, G. C. 1972. Evaluating of aphid population on plants. : Aphid Technology (Ed. H.V. Van Emden.) Academic Press, New York. pp. 105-
145.

Lal, B. S. 1964. Vegetable pests: Entomology in India, Entomological Society of India, IARI, New Delhi, pp. 187-211.

Rosaih, R. 2001. Evaluation of different botanicals against the pest complex of brinjal. Pestology, 52: 14-16.

Satpathy, J.M. 1973. Field tested with granulated insecticides for the control of L orbonalis. Indian J. Agri. Sci., 43: 1081-1086.

Tewari, G. C., Kumar, N. K. K. and Moorthy, P. N. K. 1984. Optimizing the dose and spray interval of synthetic Pyrethroids against brinjal shoot and fruit borer (Leucinodes orbonalis Guen.). Entomon, 9: 197-200.

Vevai, E. J. 1970. Know your crop, its pest problems and control: Brinjal. Pesticides, 4: 26-33.

\section{How to cite this article:}

Kumar, R., M.K. Mahla, G. Chhangani, B. Singh and Kumar, V. 2018. Diversity of Insect Pests and their Natural Enemies in Brinjal. Int.J.Curr.Microbiol.App.Sci. 7(07): 3714-3717. doi: https://doi.org/10.20546/ijcmas.2018.707.429 